\title{
Kecocokan Habitat Bertelur Penyu Sisik Eretmochelys imbricate, Linnaeus, 1766 (Reptilia : Cheloniidae) di Balai Taman Nasional Laut Kepulauan Seribu, Jakarta
}

\author{
Dodi Rachman*, Edi Wibowo Kushartono, Gunawan Widi Santosa \\ Departemen IImu Kelautan, Fakultas Perikanan dan Ilmu Kelautan, Universitas Diponegoro \\ JI. Prof. H. Soedarto S.H, Tembalang,Semarang, Jawa Tengah 50275 Indonesia \\ ${ }^{*}$ Corresponding author, e-mail: dodialrmd.dr@gmail.com
}

\begin{abstract}
ABSTRAK : Penyu Sisik (Eretmochelys imbricata) adalah penyu yang memiliki ciri khas moncong berbentuk paruh, rahang atasnya melengkung ke bawah dan relatif tajam seperti burung kakak tua sehingga sering disebut "Hawksbill turtle". Penyu jenis ini adalah pemakan terumbu karang yang tidak sehat sehingga terumbu karang menjadi sehat kembali.Tujuan dari penelitian ini adalah Mengetahui lokasi atau hotspot area peneluran penyu di Pulau Peteloran Timur Balai Taman Nasional Laut Kepulauan Seribu dan Mengetahui karakteristik habitat penyu dalam memilih lokasi bersarang dan bertelur. Metode yang digunakan dalam penelitian ini adalah metode Survey Deskriptif. Pengumpulan data dilakukan dengan cara observasi langsung di lapangan meliputi pengukuran panjang, lebar, dan kemiringan pantai, pengukuran suhu, identifikasi vegetasi pantai, predator dan kelembaban sarang serta pengukuran jenis substrat sarang di laboratorium geologi Universitas Diponegoro. Penentuan stasiun pengamatan menggunakan metode Purposive Random Sampling. Hasil penelitian menunjukkan ditemukannya 2 sarang Penyu Sisik (Eretmochelys imbricata) di bagian sebelah timur pulau dengan total jumlah 390 butir telur. Panjang pantai Pulau Peteloran Timur setiap stasiunnya berkisar 4,80-13,20 m, lebar pantainya $12-19,60 \mathrm{~m}$. Kemiringan pantai Pulau Peteloran Timur mencapai $0,07-0,23^{\circ}$. Hasil pengukuran suhu berkisar $31-34{ }^{\circ} \mathrm{C}$. Kadar air sedimen berkisar antara 0,002-0,004 \%. Ukuran butir pasir Pulau Peteloran Timur didominasi pasir kasar dengan mencapai 48,55\%. Vegetasi yang mendominasi adalah Pandan (Pandanus tectorius) selebihnya vegetasi campuran. Predator yang dijumpai di lapangan adalah Biawak (Varanus salvator).
\end{abstract}

Kata Kunci : Eretmochelys imbricata, Habitat, Pulau Peteloran Timur

\section{Suitability of Eretmochelys imbricate Hawksbill Turtles, Linnaeus, 1766 (Reptilia: Cheloniidae) at the Marine National Park Hall, Seribu Islands Jakarta}

\begin{abstract}
Hawksbill turtle (Eretmochelys imbricata) is a turtle that has the characteristics of a half-shaped muzzle, its upper jaw is curved downward sharply and often called the "Hawksbill Turtle". This type of turtle is an unhealthy coral reef eater so that the coral reefs are able to maintain its healthy condition. The purpose of this research is to know the location or hotspot area of turtle nesting in the east peteloran, Seribu Archipelago national park and to know the habitat characteristics of turtle in choosing nesting and laying eggs location. The method used in this research was descriptive survey method. The data collection were done by direct observation in a long-distance field by assessing the width, and coastal slope, temperature measurement, predator and humidity of nest and measurement of nest type in the geological laboratory of Diponegoro University. Determination of the location was determined by purposive random sampling method. The results showed 2 Hawksbill nests (Eretmochelys imbricata) in the eastern part of the island had a total of 390 eggs. The length of the East Peteloran Island beach each station ranged from 4.80 to $13.20 \mathrm{~m}$, the beach width of $12-19.60 \mathrm{~m}$. The eastern coastal slope of East Peteloran Island reached 0.07-0.23 . The temperature measurements ranged from $31-34^{\circ} \mathrm{C}$. Sediment air content ranged from $0.002-0.004 \%$. The size of the sand grains of East Peteloran Island was dominated by a sand average of $48.55 \%$. Vegetation that dominates were Pandan (Pandanustectorius) and the others were mixed vegetation. Predator found in the field was monitor Lizards (Varanussalvator).
\end{abstract}


Keywords: Eretmochelys imbricata, Habitat, Peteloran Timur Island PENDAHULUAN

Penyu sisik tersebar di wilayah Indonesia terutama di pulau-pulau kecil yang tidak berpenghuni. Sebagian besar penyu sisik ditemukan di Kepulauan Riau hingga Belitung, Lampung, Kepulauan Seribu, Kepulauan Karimunjawa, Laut Sulawesi (Berau), Sulawesi Selatan (Takabonerate) hingga Sulawesi Tenggara (Wakatobi), Maluku dan Papua (Ka, 2000).

Populasi Penyu Sisik di Indonesia terus menurun. Penurunan populasi Penyu Sisik di alam disebabkan terutama oleh faktor manusia (pencurian telur penyu, perburuan penyu, pendegradasi habitat penyu dan pengambilan sumber daya alam laut yang menjadi makanan penyu) dibandingkan dengan faktor alam dan predator (Adnyana, 2009). Kondisi inilah yang menyebabkan semua jenis penyu di Indonesia diberikan status dilindungi oleh Negara sebagaimana tertuang dalam PP Nomor 7 tahun 1999 tentang Pengawetan Jenis-jenis Tumbuhan dan Satwa yang Dilindungi. Secara internasional, penyu masuk ke dalam daftar merah (redlist) di International Union for Conservation Nature and Natural Resources (IUCN) tahun 2004 dan Appendix I CITES yang menetapkan keberadaan penyu di alam telah terancam punah sehingga segala bentuk pemanfaatan dan peredarannya harus mendapat perhatian secara serius.

Tingkat pemanfaatan yang tinggi serta intensif ditambah dengan kerusakan habitat peneluran diduga menyebabkan populasi penyu kian menurun. Oleh karena itu perlu dilakukan upaya untuk meningkatkan populasi penyu, salah satunya dengan melakukan penataan tempat peneluran (nesting site). Seleksi tempat peneluran penyu diduga erat kaitannya dengan kondisi biologi yang perlu diperhatikan antara lain jenis vegetasi yang mendominasi di pantai peneluran sedangkan kondisi fisik pantai antara lain, jenis substrat, kemiringan pantai, panjang dan lebar pantai (Yayasan Alam Lestari, 2000).

\section{MATERI DAN METODE}

Materi yang digunakan dalam penelitian ini adalahPenyu Sisik (Eretmochelys imbricata) yang meliputi habitat sarang peneluran penyu antara lain: sedimen, suhu, kemiringan pantai, panjang dan lebar pantai, kadar air, vegetasi dan predator di Pulau Peteloran Timur, Taman Nasional Kepulauan Seribu, DKI Jakarta.Data pendukung yang digunakan adalah data rekapitulasi jumlah sarang penyu dan telur Penyu Sisik (Eretmochelys imbricata) di Kepulauan Seribu dari Balai Taman Nasional Kepulauan Seribu DKI Jakarta.

Penelitian ini dilaksanakan pada tanggal 7 Maret - 17 Maret 2017 yang bertempat di Pulau Peteloran Timur, Taman Nasional Kepualaun Seribu, Provinsi DKI Jakarta. Metode yang digunakan dalam penelitian ini adalah metode survey deskriptif. Metode survey secara deskriptif merupakan metode penelitian yang digunakan untuk mendapatkan informasi dan gambaran suatu keadaan di dalam suatu komunitas secara sistematik (Notoatmodjo, 2002). Pengumpulan data dilakukan dengan cara observasi langsung di lapangan dan dilakukan pengukuran serta uji laboratorium.

Penentuan stasiun pengambilan sample ditentukan berdasarkanmetode purposive random sampling, yaitu penentuan dengan pertimbangan tertentu oleh peneliti (Nazir, 1988). Pertimbangan yang digunakan untuk menentukan stasiun pengambilan sampel dan identifikasi vegetasi adalah panjang pantai dan intensitas peneluran penyu di pantai tersebut. Penelitian ini terbagi atas 4 stasiun dimana dengan asumsi dapat mewakili perairan tersebut. Berikut adalah peta penelitian selengkapnya pada Gambar 1.

Lebar pantai diukur dari jarak pasang tertinggi sampai dengan vegetasi terluar dengan roll meter untuk lebar supratidal. Lebar intertidal diukur dari jarak pasang tertinggi sampai dengan batas surut. Panjang pantai diukur mengikuti garis pantai (Yayasan Alam Lestari, 2000).

Pengukuran kemiringan pantai pada setiap titik dengan menggunakan tongkat berskala. Roll meter ditarik dari titik daratan lalu diikat pada tongkat tegak yang ditancapkan. Tali yang direntangkan diatur sampai membentuk sudut $90^{\circ}$ dengan tongkat. Bentangan roll meter $(\mathrm{x})$ dan tinggi tongkat (y). Untuk memudahkan pengukuran panjang tali ditetapkan terlebih dahulu.

\section{Suhu dan Kelembaban Sarang}


Pengukuran suhu dan kelembaban sarang diukur dengan menggunakan thermo hygrometer digital pada tiap sarangnya. Pengukuran dilakukan pada substrat bawah permukaan sedalam telur pertama kali dijumpai kemudian mencatat hasilnya. Pengamatan suhu dankelembaban substrat diharapkan dapat mewakili kondisi suhu dan kelembaban substrat dalam sarang telur penyu tersebut.

\section{Pengukuran Kadar Air Sedimen}

Data kadar air diambil pada bagian permukaan pasir, bagian tengah dan di bawah permukaan pasir permukaan tersebut. Data tersebut diharapkan dapat mewakili kondisi kadar air sedimen dalam sarang telur penyu. Widada et al., (2003) menjelaskan sampel dalam keadaan alami diambil $10 \mathrm{~g}$ kemudian dioven hingga kering. Setiap sampel diukur tiga kali percobaan. Rumus perhitungan persentase kadar air pada sedimen menurut Widada et al., (2003.

\section{Pengukuran Butiran Sedimen}

Substrat pasir pantai yang akan dianalisis ukuran butirnya diambil pada permukaan, bagian tengah dan pada kedalaman sekitar telur agar mewakili kedalaman sarang. Substrat diayak kering berdasarkan metode Buchanan dalam Holme and Mc Intyre, 1984). Jenis analisis untuk mendapatkan ukuran butir meliputi analisis ayakan dan analisis hidrometer. Metode pengayakan substrat sedimen dilakukan dengan cara penyaringan (sieve) menggunakan sieve shaker.

Penyu Sisik (Eretmochelys imbricata) yang akan bertelur sejak naik ke pantai hingga kembali lagi ke laut diamati. Menurut Yayasan Alam Lestari (2000), data penyu sisik yang dicatat meliputi : Panjang karapas, lebar karapas, jumlah penyu naik, serta jumlah penyu yang bertelur.

Pengamatan vegetasi dan satwa yang berpotensi sebagai predator dilakukan dengan mencatat jenis vegetasi dan predator yang terdapat di pulau Peteloran Timur selama penelitian. Pengamatan keanekaragaman satwa yang ada di daerah peneluran penyu di PulauPeteloran Timur, Taman Nasional Laut Kepulauan Seribu dilakukan pengamatan terhadap gangguan peneluran penyu dengan cara pengamatan langsung di lapangan.
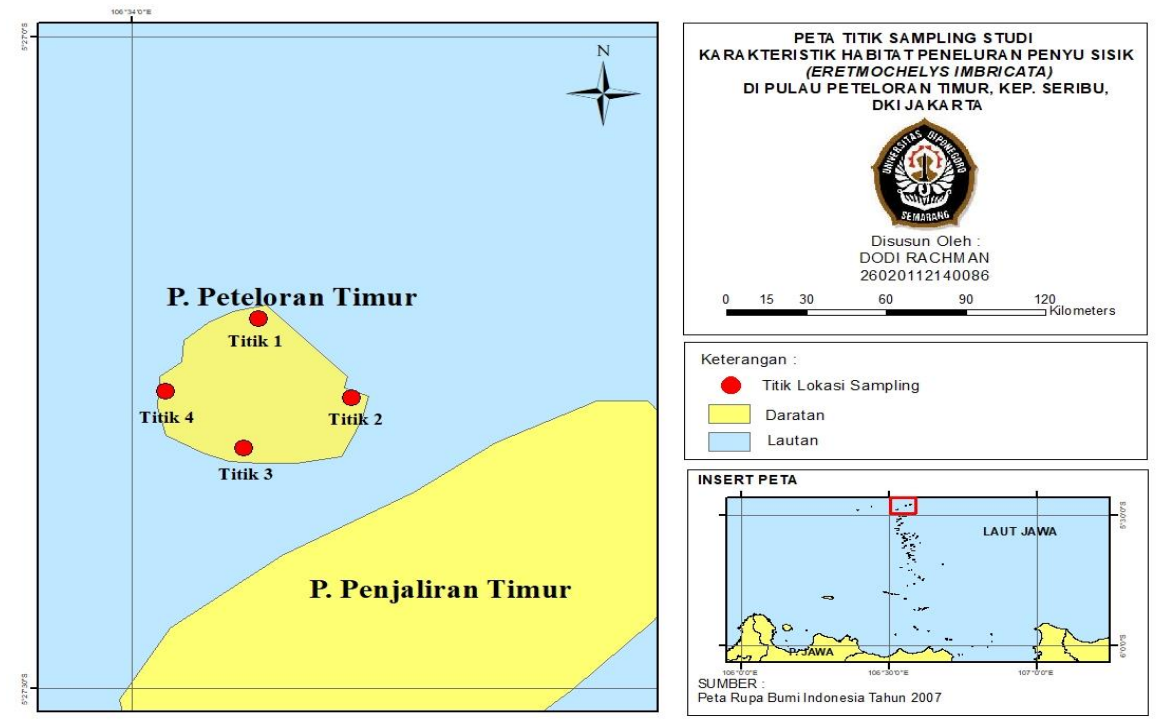

Gambar 1. Peta Penelitian di Pulau Peteloran Timur Kepulauan Seribu, DKI Jakarta

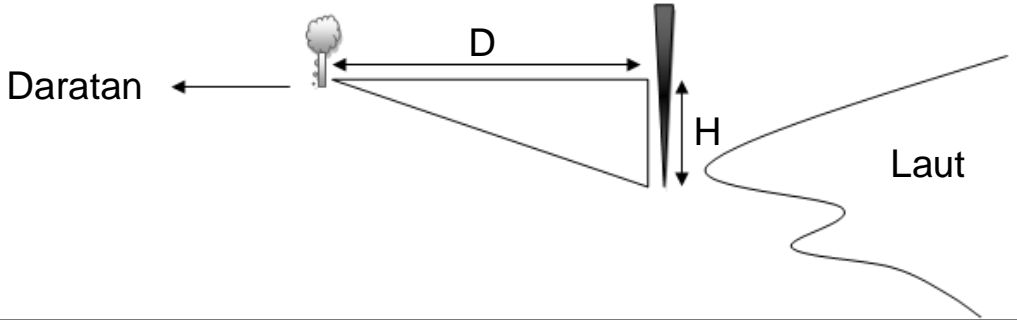


Gambar 2. Teknik Pengukuran Kemiringan Pantai

Analisis data menggunakan cara deskriptif, yang bertujuan untuk membuat deskripsi mengenai situasi dan kejadian secara sistematik, dengan menjelaskan hasil perhitungan di lapangan maupun di laboratorium (Nazir, 2005). Pengumpulan data dilakukan dengan cara observasi langsung di lapangan dan dilakukan pengukuran serta analisa laboratorium. Dalam penelitian ini data yang diperoleh meliputi : data panjang dan lebar pantai, kemiringan pantai, suhu pasir, kadar air, partikel pasir, jumlah penyu yang bertelur, vegetasi dan predator. Data tersebut dikaji berdasarkan peristiwa yang ada dan diperkuat dengan data sekunder yang ada dan referensi ilmiah lainnya.

\section{HASIL DAN PEMBAHASAN}

Hasil pengamatan pada tanggal 7 Maret - 14 Maret 2017di Pulau Peteloran Timur, terdapat jenis penyu yang ditemukan, yaitu Penyu Sisik (Eretmochelys imbricata). Penyu Sisik (Eretmochelys imbricata)ditemukan aktifitas peneluran di Pulau Peteloran Timur hal ini dibuktikan dengan ditemukannya dua sarang penyu pada saat pengambilan data di lapangan yang terlihat pada

Penemuan sarang dan telur Penyu Sisik (Eretmochelys imbricata)terletak di pulau bagian

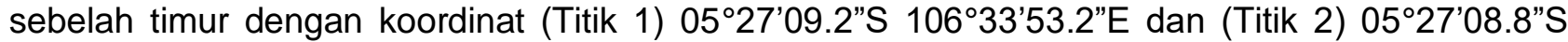
$106^{\circ} 33^{\prime} 53.1^{\prime \prime}$. pada sarang pertama berjumlah 205 butir dan untuk sarang kedua berjumlah 185 butir. Total jumlah telur yang ditemukan di pulau peteloran timur selama penelitian berlangsung sebanyak 390 butir.

\section{Jumlah Sarang Penyu Berdasarkan Lokasi}

Dari hasil pengamatan pada penyu yang bersarang di Pulau Peteloran Timur menunjukan bahwa penyu yang bertelur di bagian wilayah timur berjumlah 2 ekor penyu. Setiap sarang yang diteliti memiliki karakteristik pantai yang beragam, yakni suhu sarang, kelembaban sarang, lebar pantai, kemiringan pantai, dan kadar air sedimen yang berbeda-beda. Hasil pengukuran suhu sarang pada setiap lokasi peneluran penyu di timur pulau peteloran pada saat setelah penyu melakukan proses bertelur yaitu berkisar antara $31^{\circ} \mathrm{C}$ dan $34^{\circ} \mathrm{C}$, Pengukuran kelembaban di bagian tiap sarang penyu diperoleh kelembaban $61 \%$ dan $41 \%$.

Lebar pantai pada timur pulau berkisar $19,60 \mathrm{~m}$, pada bagian barat pulau berkisar $11,10 \mathrm{~m}$, pada bagian utara pulau berkisar $17 \mathrm{~m}$, pada bagian selatan pulau berkisar $12 \mathrm{~m}$. Lebar Pantai Peteloran Timurdibagian timur secara keseluruhan lebih lebar dibandingkan lebar Pantai Pulau Peteloran dibagian lainnya.

Kemiringan pantai di setiap stasiun dan setiap sarang merupakan pantai yang datar dimana ditemukan kemiringan pantai yang paling besar $0,23^{\circ}$ pada bagian utara dan paling kecil ditemukan bagian timur yaitu $0,07^{\circ}$ dan untuk bagian sarang kemiringan pantai paling besar yaitu pada bagian sarang $20,10^{\circ}$ sedangkan yang paling kecil ditemukan pada bagian sarang 1 dengan kemiringan pantai $0,09^{\circ}$.

\section{Pengukuran Kadar Air Sedimen}

Kadar air pada paling tinggi di Pulau Peteloran Timur pada setiap stasiunnya ditemukan pada bagian luar dan paling kecil pada bagian dalam, sedangkan pada bagian sarang bagian paling besar yaitu bagian tengah. Hasil pengamatan karakteristik habitat peneluran di Pulau Peteloran (Tabel 4).

\section{Ukuran dan Tekstur SubstratSedimenPulau Peteloran Timur}

Daerah peneluran sebagai ruang tempat bertelur penyu, mempunyai karakteristik yang menarik naluri penyu untuk membuat sarang. Karakteristik substrat pantai sebagai media tempat penyu bertelur dapat dilihat pada Tabel 5. Keadaan tekstur pasir pada Pulau Peteloran pada setiap stasiunnya serta tiap sarangnya yang pada umumnya berwarna putihkecoklatan dengan ukuran yang bervariasi dari pasir sangat kasar, kasar, sedang, halus, dan sangat halus. Setiap stasiun ditemukan tekstur pasir yang bervariasi namun pasir tersebut didominasi oleh pasir yang bertekstur kasar, Nilai pasir sangat kasar ditemukan pada lokasi timur bagian tengah dengan nilai 
$81,86 \%$, sedangkan untuk nilai pasir sangat halus paling tinggi pada selatan bagian luar dan sarang 1 pada bagian dalam.

Tabel 1. Pengamatan Penyu yang Bertelur di Pulau Peteloran Timur

$\begin{array}{ccc}\text { Jenis Penyu } & \text { Jumlah (sarang) } & \text { Jumlah telur (butir) } \\ \text { Penyu sisik } & 2 & 390 \\ \text { Total } & 2 & 390\end{array}$

Tabel 2. Hasil pengamatan jumlah sarang penyu berdasarkan lokasi

\begin{tabular}{|c|c|c|c|}
\hline \multicolumn{3}{|c|}{ Lokasi Sarang } & \multirow{2}{*}{ Jumlah (sarang) } \\
\hline Timur & Barat Utara & Selatan & \\
\hline 1 & & & 1 \\
\hline 2 & & & 1 \\
\hline & Total & & 2 \\
\hline
\end{tabular}

Tabel 3. Karakteristik Habitat Peneluran Penyu di Pulau Peteloran Timur

\begin{tabular}{cccccc}
\hline \multirow{2}{*}{ No } & Lokasi & \multicolumn{4}{c}{ Karakteristik Pantai } \\
\cline { 3 - 6 } & $\begin{array}{c}\text { Suhu } \\
\text { Sarang }\end{array}$ & $\begin{array}{c}\text { Kelembaban Sarang } \\
(\%)\end{array}$ & $\begin{array}{c}\text { Lebar Pantai } \\
(\mathrm{m})\end{array}$ & $\begin{array}{c}\text { Kemiringan } \\
\text { Pantai }\left({ }^{\circ}\right)\end{array}$ \\
\hline 1 & Timur & - & - & 19,60 & 0,7 (datar) \\
2 & Barat & - & - & 11,10 & 0,12 (datar) \\
3 & Utara & - & - & 17 & 0,23 (datar) \\
4 & Selatan & - & - & 12 & 0,08 (datar) \\
5 & Sarang Timur 1 & 31 & 61 & 17,80 & 0,09 (datar) \\
6 & Sarang Timur 2 & 34 & 41 & 16,70 & 0,10 (datar) \\
\hline
\end{tabular}

Tabel 4. Pengukuran Kadar Air Sedimen di Pulau Peteloran Timur

\begin{tabular}{|c|c|c|c|c|c|c|c|}
\hline \multirow{3}{*}{ No } & \multirow{3}{*}{ Lokasi } & \multicolumn{6}{|c|}{ Kadar Air Sedimen (\%) } \\
\hline & & \multicolumn{3}{|c|}{ Bagian sampel } & \multicolumn{3}{|c|}{ Bagian Sarang } \\
\hline & & Luar & Tengah & Dalam & Atas & Tengah & Dalam \\
\hline 1 & Timur & 0,002 & 0,002 & 0,001 & - & 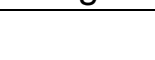 & - \\
\hline 2 & Barat & 0,003 & 0,001 & 0,001 & - & . & 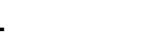 \\
\hline 3 & Utara & 0,004 & 0,001 & 0,001 & - & 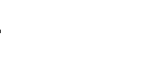 & 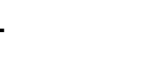 \\
\hline 4 & Selatan & 0,003 & 0,001 & 0,001 & - & . & - \\
\hline 5 & Sarang 1 & - & - & - & 0,002 & 0,003 & 0,002 \\
\hline 6 & Sarang 2 & - & - & - & 0,004 & 0,004 & 0,003 \\
\hline
\end{tabular}

Keterangan : Bagian Sampel Luar : Pengambilan di bagian bibir pantai; Bagian Sampel Tengah : Pengambilan sampel di bagian tengah; Bagian Sampel Dalam : Pengambilan sampel dekat vegetasi

\section{Vegetasi di Pulau Peteloran Timur}

Kondisi vegetasi di Pulau Peteloran Timur tergolong tipe hutan pantai. Hasil pengamatan dilapangan menunjukkan Pulau Peteloran Timur ditumbuhi vegetasi hutan pantai yang memiliki sifat khas, tersusun dengan vegetasi campuran yang terdiri dari pohon-pohon tumbuhan perdu, semak dan belukar. Vegetasi pada Pantai Paloh didominasi oleh tumbuhan Cemara Laut (Casuarina equisetifolia). Disetiap bagian Pulau Peteloran Timur terdapat macam-macam habitat vegatasi di pinggir pantai antara lain: Tapak Kuda / Tapak kambing (Ipomoea pes-caprae), 
Cemara Laut (Casuarina equisetifolia), Jati Pasir (Guettarda speciosa), Bakung - bakung (Scaevola taccada), Pandan Duri (Pandanus tectorius), Bunga Matahari Pantai (Helianthus debilis), Pohon Kelapa (Cocos nucifera). Hasil penelitian menunjukkan bahwa terdapat sarang penyu di bagian timur pulau peteloran karena di bagian tersebut ditemukan vegetasi yang lebih rapat dibandingkan bagian lainnya.

\section{Jenis Satwa di Pulau Peteloran Timur}

Pulau Peteloran Timur tidak hanya sebagai habitat peneluran penyu, tetapi juga merupakan habitat bagi beberapa satwa lainnya yang sebagian merupakan predator yang berpotensi bagi telur-telur penyu dan tukik. Berdasarkan hasil pengamatan di daerah peneluran penyu sepanjang Pulau Peteloran Timur jenis satwa lain yang dijumpai meliputi: Burung Belibis Batu (Dendrocyna javanica), Tikus Pohon (Rattus tiomanicus), Gagak Hutan (Corvus enca),Biawak (Varanus salvator).

Penelitian yang dilakukan di Pulau Peteloran Timur, menunjukkan bahwa terdapat satu jenis penyu yang mendarat dipantai ini yaituPenyu Sisik (Eretmochelys imbricata). Populasi penyu di Pulau Peteloran Timur sangat besar, hal ini dibuktikan dari hasil penelitian yang menemukan penyu mendarat.Hal ini didukung oleh lokasinya yang berhadapan langsung dengan lautan terbuka, kerapatan vegetasi pantai yang tinggi dan tingkat intensitas cahaya yang rendah karena berada jauh dari pemukiman.

Jumlah terlur Penyu Sisik (Eretmochelys imbricata) pada saat pengambilan data dari sarang pertama berjumlah 205 butir dan pada sarang kedua berjumlah 185 butir. Jumlah telur penyu yang di temukan pada bulan maret berkisar berjumlah 1.781 butir dari 11 sarang yang ditemukan. Berdasarkan hasil pengamatan memperlihatkan bahwa pada bagian timur pulau peteloran timur ditemukan dua sarang penyu dibandingkan pada bagian pulau yang lainnya. Hal ini dikarenakan kondisi pantainya yang sesuai atau memenuhi ketentuan sebagai lokasi peneluran serta minimnya aktifitas manusia. Yayasan Alam Lestari (2000), menjelaskan cahaya yang dapat terlihat dari pantai akan mengganggu induk penyu yang akan bertelur dan menyulitkan tukik yang baru menetas yang akan bergerak menuju laut.

Tabel 5. Tekstur Substrat Sedimendi Pulau Peteloran Timur

\begin{tabular}{ccccccc}
\hline \multirow{2}{*}{ Lokasi } & \multicolumn{5}{c}{ Komposisi Pasir(\%) } & Kategori \\
\cline { 2 - 5 } & Sangat Kasar & Kasar & Sedang & Halus & Sangat Halus & (Triangulasi) \\
\hline Timur (luar) & 22,98 & 63,05 & 10,29 & 3,08 & 0,42 & Pasir \\
Timur (tengah) & 81,86 & 14,62 & 3,08 & 0,94 & 0,20 & Pasir \\
Timur (dalam) & 9,54 & 51,99 & 32,66 & 4,77 & 0,18 & Pasir \\
Barat (luar) & 21,18 & 49,49 & 17,45 & 10,74 & 0,39 & Pasir \\
Barat (tengah) & 50,62 & 46,72 & 1,43 & 0,44 & 0,09 & Pasir \\
Barat (dalam) & 4,90 & 56,57 & 32,96 & 4,16 & 0,73 & Pasir \\
Utara (luar) & 37,78 & 46,35 & 5,31 & 8,76 & 1,50 & Pasir \\
Utara (tengah) & 36,17 & 42,57 & 15,36 & 5,99 & 0,10 & Pasir \\
Utara (dalam) & 28,76 & 60,45 & 8,19 & 1,08 & 0,06 & Pasir \\
Selatan (luar) & 16,40 & 64,61 & 13,79 & 4,70 & 0,05 & Pasir \\
Selatan (tengah) & 3,75 & 40,20 & 47,60 & 7,43 & - & Pasir \\
Selatan (dalam) & 1,13 & 27,24 & 60,36 & 11,16 & 0,07 & Pasir \\
Sarang Timur 1 (atas) & 4,04 & 47,04 & 41,27 & 5,28 & 0,09 & Pasir \\
Sarang Timur 1 (tengah) & 2,53 & 32,28 & 56,03 & 7,08 & 0,05 & Pasir \\
Sarang Timur 1 (dalam) & 25,87 & 36,79 & 32,61 & 3,4 & 0,05 & Pasir \\
Sarang Timur 2 (luar) & 4,33 & 73,1 & 20,6 & 1,19 & 0,23 & Pasir
\end{tabular}




$\begin{array}{lllllll}\text { Sarang Timur } 2 \text { (tengah) } & 25,75 & 55,68 & 16,73 & 0,95 & 0,07 & \text { Pasir } \\ \text { Sarang Timur } 2 \text { (dalam) } & 27,40 & 64,55 & 7,8 & 0,71 & 0,06 & \text { Pasir }\end{array}$

Hasil pengukuran suhu pada sarang pertama yaitu $31^{\circ} \mathrm{C}$ dan pada sarang kedua $34^{\circ} \mathrm{C}$. Hasil pengamatan menunjukkan bahwa penyu naik dan bersarang pada malam hari, hal tersebut menurut Lutz dan Musick (1997) karena penyu lebih memilih tempat dengan pasir kering dan suhu yang tidak terlalu tinggi yang sesuai dengan kebutuhan telur-telurnya agar dapat bertahan hidup. Suhu juga akan menentukan rasio kelamin anak penyu, penyu yang lahir dari sarang yang suhu inkubasinya antara 28 - 29으 kemungkinan besar akan menghasilkan penyu berkelamin jantan sedangkan suhu inkubasinya antara 30 - 31ํㅡ kemungkinan besar akan menghasilkan penyu berkelamin betina. Hasil penelitian menunjukkan bahwa kelembaban di Pulau Peteloran sesuai bagi penyu untuk mendarat menuju pantai dan membuat sarang. Menurut Segara (2008), kelembaban pasir yang sesuai berkisar 69 - 95\%. Kelembaban dalam sarang sangat dibutuhkan untuk perkembangan embrio penyu secara normal. Miller (1997), berpendapat bahwa pasir yang solid dengan kadar air tepat mampu menyangga bentuk ruang pada telur. Menurut Yayasan Lestari (2000), kandungan air dalam pasir merupakan faktor penting dalam pertumbuhan embrio dan penetasan telur. Oleh karena itu, induk akan lebih memilih tempat dengan kelembaban tepat.

Faktor lainnya yang mempengaruhi tingkat kelembaban adalah seperti faktor-faktor tumbuhan antara lain bentuk perakaran, daya tahan terhadapkekeringan, tingkatpertumbuhan. Faktor iklim antara lain temperatur, kelembaban dan kecepatan angin. Kelembaban bagian dalam sarang juga memiliki nilai yang cukup konstan karena dipengaruhi oleh beberapa faktor ekologi antara lain: kedalaman, jarak sarang dari pasang tertinggi dan curah hujan yang terjadi serta kemampuan pasir untuk menyerap air.

Hasil pengukuran lebar pantai pada bagian timuryaitu sesuai dengan pernyataan Nuitja (1992) yang menjelaskan bahwa penyu lebih memilih meletakkan telur-telurnya diatas pasang surut antara 30 - $80 \mathrm{~m}$. Ditambahkan dengan hasil penelitian Datusahlan et al., (2011), menyatakan bahwa lebar Pulau Peteloran Timur tidak jauh berbeda dengan lebar pantai peneluran penyu di Pulau Derawan Kalimantan Timur yaitu sebesar 15 - 26 m.Secara umum, semua jenis penyu cenderung untuk bertelur di atas tanda tinggi air penggenangan pasang surut agar telur tidak terendam air laut (Varela-Acevedo et al., 2009). Daerah itu akan menarik naluri penyu untuk membuat sarang. Jauh dekatnya lebar pantai sangat dipengaruhi oleh besar kecilnya gelombang.

Lebar pantai berkorelasi baik dengan luas tempat yang tersedia untuk penyu bersarang (Varela-Acevedo et al., 2009). Perbedaan ini disebabkan oleh perbedaan kondisi perairan yang di bagian timur dan bagian lainnya. Kondisi perairan di bagian timur lebih tenang di bagian lainnya karena pada saat penilitan sedang terjadi angin muson barat yang menyebabkan abrasi di beberapa bagian pulau tersebut. Kemiringan pantai sangat berpengaruh pada banyaknya penyu yang membuat sarang karena semakin curam pantai, maka semakin besar pula energi penyu yang diperlukan untuk naik bertelur dan semakin sulit penyu melihat obyek yang berada jauh didepan karena matanya penyu mampu melihat dengan baik pada sudut $150^{\circ}$ kearah bawah (Symthe, 1975).

Menurut Nuitja (1992), bahwa kondisi pantai yang datar(0 - $3 \%$ ) landai (3 - $8 \%$ ) dan miring (8 - $16 \%$ ) sesuai bagi habitat peneluran penyu karena kondisi landai tersebut dapat memudahkan penyu untuk mencapai tempat peneluran. Kemiringan pada setiap sisi pada pulau ini ideal sebagai lokasi sarang peneluran. Yayasan Alam Lestari (2000) menjelaskan berubahnya formasi pantai karena abrasi akan mengakibatkan kemiringan pantai bertambah tinggi dan berkurangnya luas pantai untuk lokasi peneluran.

Menurut Yayasan Alam Lestari (2000), kandungan air dalam pasir merupakan faktor penting dalam pertumbuhan embrio dan penetasan telur. Kadar air di Pulau Peteloran Timur bagian timur lebih cenderung stabil, sedangkan pada bagian pulau Peteloran lainnya cenderung kurang stabil. Perbedaan ini disebabkan karena pada bagian barat, utara, dan selatan lebih terbuka terhadap udara dan sinar matahari, sedangkan di bagian timur substratnya dilindungi oleh vegetasi pantai, sehingga kadar airnya lebih stabil. Vegetasi pada pantai akan melindungi substrat dan telur terhadap perubahan kadar air yang drastis. 
Hasil analisa terhadap ukuran butir disetiap lokasi pulau Peteloran Timur menunjukkan bahwa pantai ini merupakan lokasi yang ideal untuk penyu membuat sarang dan meletakkan telurnya. Kondisi pasir di pulau peteloran sangat mendukung dalam proses penggalian sarang, sebab jika didominasi oleh pasir halus, debu dan liat, sarang yang digali akan mudah runtuh, apalagi jika kondisi hujan. Hal ini akan menyebabkan terjadi kelengketan antara tanah dan telur sehingga menyebabkan telur ditumbuhi jamur dan akan membusuk dengan cepat. Kondisi pasir pulau peteloran timur yang didominasi pasir kasar, sangat mendukung proses pengeraman telur karena pasir kasar cocok untuk penyebaran udara secara merata ke dalam sarang. Hal ini sangat penting untuk proses metabolism dari perkembangan dan pertumbuhan telur embrionik yang mutlak memerlukan kemantapan suhu dan oksigen yang cukup. Hal ini memperkuat pendapat Nuitja (1992), bahwa tempat yang dapat dijadikan untuk tujuan bertelur dan disukai penyu adalah tempat yang memiliki butiran pasirkasar/sedang yang tidak kurang 90\%-nya adalah pasir kasar, selebihnya pasir halus, debu dan liat.

Vegetasi adalah salah satu parameter yang menjadi ciri dari pantai peneluran penyu. Vegetasi berperan sebagai tempat berlindung penyu pada saat bertelur sehingga dapat terhindar dari predator. Selain itu, vegetasi akan mengurangi pengaruh langsung sinar matahari ke dalam sarang yang berpengaruh terhadap kestabilan suhu sarang, karena semakin tinggi penutupan vegetasinya maka semakin stabil suhu dalam sarang, (Nuitja, 1992).

Vegetasi di bagian timur dan utara pulau Peteloran Timur didominasi olehPandan Duri (Pandanus tectorius) Cemara Laut (Casuarinaceae equisetifolia)dan Bakung - bakung (Scaevola taccada). Keberadaan vegetasi ini cenderung menarik naluri induk penyu untuk membuat sarang dan meletakkan telurnya.Hasil penelitian menunjukkan sarang yang ditemukan berada tepat dibawah naungan vegetasi Scaevola taccada berada di sisi timur Pulau Peteloran Timur, disemua bagian pulau memiliki kerapatan yang cukup baik namun pada sisi timur pulau ditemukan kerapatan yang lebih dibandingkan sisi lainnya. Hal ini sesuai dengan penyataan Nuitja (1992), bahwa daerah peneluran penyu berhubungan erat dengan kondisi vegetasi terutama kerapatan yang berkaitan dengan penutupan vegetasi, dimana semakin rapat kondisi vegetasi maka penutupan vegetasinya juga semakin besar karena kerapatan vegetasi akan menghalangi intensitas cahaya yang masuk ke dasar vegetasi sehingga memberikan ketenangan ataa rasa aman pada saat penyu akan bertelur menuju sarang peneluran.

Predator merupakan salah satu ancaman terhadap telur dan tukik. Apabila predator jumlahnya melimpah, maka penyu betina akan mencari lokasi lain untukbertelur. Hal ini mengancam keberadaan populasi penyu di Indonesia. Menurut Nontji (2005), fase tukik adalah masa paling kritis dalam hidupnya karena pada saat itulah predator paling mudah untuk memangsanya, baik ketika sedang berada di pasir maupun setelah berada di laut. Hasil pengamatan di lapangan, beberapa jenis fauna yang hidup di sepanjang Pulau Peteloran Timur sebagai predator antara lain, Burung Kuntul Karang (Egretta sacra), Elang Laut (Haliaeetus leucogaster), Kepiting Pantai (Ocypoda sp.), danBiawak (Varanus salvator).

\section{KESIMPULAN}

Penyu Sisik (Eretmochelys imbricata) cenderung mendarat dan bertelur di bagian sebelah Timurpulau Peteloran Timur dibandingkan di bagian pulau Peteloran lainnya. Hal ini didukung oleh lokasinya yang berhadapan langsung dengan lautan terbuka (Laut Jawa), vegetasi yang rapat sekaligus tingkat intensitas cahaya yang rendah karena berada jauh dari pemukiman. Telur penyu yang ditemukan yaitu berada dekat dengan vegetasi Bakung - bakung (Scaevola taccada). Kategori kemiringan pantai yang datarmembantu memudahkan penyu dalam proses mendarat, membuat sarang dan bertelur. Jenis substrat pasir sedang\& kasarjuga mempermudah penyu pada saat proses membuat sarang.

\section{DAFTAR PUSTAKA}


Adnyana, I.B.W. \& Creusa, H. 2009. Panduan Melakukan Pemantauan Populasi Penyu di Pantai Peneluran di Indonesia. WWF-Indonesia dan Universitas Udayana. Jakarta.

Buchanan, J.B. 1984. Sediment Analysis in Holme. N. A. and Mc. Intrye A. D. (Editor). Edition Blackwell Scientific Bustard, R. 1972. Sea Turtle, Natural History and Conservation. Collin, London, $220 \mathrm{p}$.

Datusahlan, M., Sudrajat \& Rukmi, D.S. 2011. Tingkat keberhasilan penetasan telur Penyu Hijau (Cheloniamyda) berdasarkan karakteristik pantai di Kepulauan Derawan Kabupaten Berau Kalimantan Timur. Jurnal Fakultas Matematika dan IImu Pengetahuan Alam Universitas Mulawarman. 10(2):189.

Ka, U.W.H.T. 2000.Mengenal Penyu. Terjemahan Akil Yusuf, Yayasan Alam Lestari, Jakarta.

Lutz, P.L. \& Musick, J.A. 1997. The Biology of Sea Turtle. Marine Science Series. CRC Press, Inc.London-Tokyo, $502 \mathrm{p}$.

Miller, J.D. 1997. Reproduction In Sea Turtles. In: Lutz, P.L dan Musick, J.A (Eds.). The Biology of Sea Turtle. CRC Press, Boca Raton, PP. $51-82$.

Nazir, M. 1988, Metode Penelitian, PT. Ghalia Indonesia, Jakarta, 90 hlm.

Nazir, M. 2005. Metode Penelitian. PT. Ghalia Indonesia, Jakarta, 622 hlm.

Nontji, A. 2005. Laut Nusantara. Penerbit Djambatan. Jakarta, 320-323 hlm.

Notoatmodjo, S. 2002. Metodologi Penelitian Kesehatan. Rineka Cipta. Jakarta, $138-140 \mathrm{hlm}$.

Nuitja, I.N.S. 1992. Biologi dan Ekologi Pelestarian Penyu Laut. IPB Press. Bogor, 127-128 hlm.

Segara, R.A. 2008. Studi karakteristik biofisik habitat peneluran Penyu Hijau (Chelonia mydas) di pantai Pangumbahan Sukabumi Jawa Barat. [Skripsi]. Fakultas Perikanan dan IImu Kelautan. Institut Pertanian Bogor.

Symthe, R.H. 1975. Vision in the Animal world. The Macmilion Press Itd. London, United Kingdom.

Varela-Acevedo, E., Eckert, K. L., Eckert, S. A., Cambers, G. \& Horrocks, J.A. 2009. Sea Turtle Nesting Beach Characterization Manual. Wider Caribbean Sea Turtle Conservation Network (WIDECAST) Marine, Conservation Biology at Duke University, Barbados Sea Turtle Project at the University of the West Indies, Sandwatch Foundation.

Widada S.M. \& Kobayashi, H. 2006. Sekilas Tentang Konservasi Sumberdaya Alam Hayati dan Ekosistemnya. Ditjen PHKA-JICA. Jakarta.

Yayasan Alam Lestari. 2000. Mengenal Penyu. Yayasan Alam Lestari dan Keidanren Nature Conservation Fund (KNCF) Jepang, $81 \mathrm{hlm}$. 